\title{
Comment \\ Different Outcomes of Acute Encephalopathy after Status Epilepticus in Patients with Dravet Syndrome. How to Avoid Them? Comment on De Liso et al. Fatal Status Epilepticus in Dravet Syndrome. Brain Sci. 2020, 10, 889
}

\author{
Charlotte Dravet
}

check for updates

Citation: Dravet, C. Different Outcomes of Acute Encephalopathy after Status Epilepticus in Patients with Dravet Syndrome. How to Avoid Them? Comment on De Liso et al. Fatal Status Epilepticus in Dravet Syndrome. Brain Sci. 2020, 10, 889. Brain Sci. 2021, 11, 792. https:// doi.org/10.3390/brainsci11060792

Academic Editor: Giovanni Assenza

Received: 8 March 2021

Accepted: 8 June 2021

Published: 16 June 2021

Publisher's Note: MDPI stays neutral with regard to jurisdictional claims in published maps and institutional affiliations.

Copyright: (C) 2021 by the author Licensee MDPI, Basel, Switzerland. This article is an open access article distributed under the terms and conditions of the Creative Commons Attribution (CC BY) license (https:/ / creativecommons.org/licenses/by/ $4.0 /)$.
Child Neuropsychiatry Unit, Fondazione Policlinico Universitario Agostino Gemelli, IRCCS, Università Cattolica del Sacro Cuore, 00168 Rome, Italy; charlotte.dravet@free.fr

\section{Dear Editor}

I read with interest the article "Fatal Status Epilepticus in Dravet Syndrome" by Paola De Liso et al. recently published in this journal [1]. The authors report in detail the cases of seven patients with Dravet syndrome who died after a febrile epileptic status (ES). They discuss the risk factors that can provoke this complication and the mechanisms that could explain the fatal issue, and ask for a therapeutic protocol in order to avoid this fatal issue. I would like underline that this type of complication, known as "Acute encephalopathy after febrile epileptic status" does not always provoke the death of the patient. That is well reported in other publications [2,3]. In particular, Tian et al. [4] reported 35 cases, including 12 patients who died and 23 who survived with massive, often irreversible, neurological regression. They note several predicting factors: early age at onset, epilepsy severity with strong pharmaco-resistance and repetitive ES, age under 5 years at the time of the event, and high fever. Here I give an example of this situation in one family. Two sisters suffering from Dravet syndrome (incomplete form without myoclonia) presented several ES during the course of their disease without complication and without neurological regression (Table 1).

However, the last ES, which occurred independently in the two patients at an interval of five months, progressed as an acute encephalopathy. The youngest died, whereas the oldest survived. The later had important neurological sequelæ, but she progressively recovered with an intensive rehabilitation; at 18 years she had recovered around $70 \%$ of her previous competences. The anamnesis of the two girls reveals that they presented some common points: severe epilepsy in the first years with repetitive ES, not a high seizure frequency before the status with the same antiepileptic drugs, and high fever during the status. However, they also presented differences: age at the epilepsy onset, age at the time of the event, coma duration, and different brain injury on MRI. The two girls carried the same SCN1A variant, inherited from the father. One explanation for the better outcome of Patient 2 could be her age, 15 years 9 months, and a low seizure frequency during late childhood and adolescence.

This type of ES is different from the usual ES which punctuate the course of Dravet syndrome. This acute encephalopathy is well known, but not explained, by the Japanese authors [5] who have shown the presence of a cerebral edema in MRI. In the cases reported by Myers et al. [6], the cerebral edema displayed by an early MRI led to a severe brain herniation that probably produced the death. The cause of this edema remains unclear, but the high temperature seems to be one prominent factor. Even if a viral infection could be the origin of this acute encephalopathy, we do not know why it is so severe. However, as advised by De Liso et al., we should alert the families and the doctors on its possible occurrence and the ways of managing it [7]. We know that these patients are prone to having "febrile" seizures. We also know these seizures are usually not provoked by a true 
fever (temperature higher than $38^{\circ} \mathrm{C}$ ), but by a temperature variation often lower than $38^{\circ} \mathrm{C}$. So, parents and caregivers should be worried when the temperature during a seizure is going up unusually in spite of the administration of antipyretic and antiepileptic drugs and they should go to the hospital quickly. If the situation persists in the emergency room, in addition to a continuous electroencephalogram, an MRI should be performed as soon as possible to detect abnormal images and signs of cerebral edema, then an antiedema treatment should be added and etiological investigations should be performed. Though the antiedema treatment did not avoid the fatal issue for the patients reported by Myers et al., it could be efficient if given at the very onset of the episode. In case it is not possible to have an MRI in an emergency, a CT scan could be performed. However, in the absence of imaging confirmation, the antiedema treatment should be implemented quickly.

Table 1. Data of the two patients.

\begin{tabular}{|c|c|c|}
\hline & Patient 1 & Patient 2 \\
\hline Date of birth & 15 September 2006 & 16 April 1999 \\
\hline Sex & Female & Female \\
\hline Age 1st seizure & $3 \mathrm{~m} \mathrm{1/2}$ & $5 \mathrm{~m} 1 / 2$ \\
\hline Cognitive development & Mild retardation, obsessive traits & Mild retardation \\
\hline$S C N 1 A$ variant & $\begin{array}{l}\text { c.4973C > G p.Thr1658Arg in } \\
\text { heterozygose, inherited from the father }\end{array}$ & c. $4973 \mathrm{C}>\mathrm{G}$ p.Thr1658Arg in heterozygose, inherited from the father \\
\hline Other ES & $\begin{array}{l}\text { Several febrile ES, one for } 4 \mathrm{~h} \text {, not } \\
\text { followed by coma and regression }\end{array}$ & $\begin{array}{l}\text { Several febrile ES in infancy and childhood, not followed } \\
\text { by coma and regression }\end{array}$ \\
\hline $\begin{array}{l}\text { Seizure frequency during } \\
\text { the year before this status }\end{array}$ & Less than monthly & No seizure in the last 22 months \\
\hline Date of the event & 6 June 2015 & 17 January 2015 \\
\hline Age at the event & 8 y $9 \mathrm{~m}$ & 15 y $9 \mathrm{~m}$ \\
\hline Current treatment & $\begin{array}{l}\text { VPA } 1450 \mathrm{mg}(40 \mathrm{mg} / \mathrm{k} / \mathrm{d} \rightarrow 115 \mu \mathrm{g} / \mathrm{mL}) \\
\text { CLB } 10 \mathrm{mg}(0.3 \mathrm{mg} / \mathrm{k} / \mathrm{d}) \\
\text { LEV } 1800 \mathrm{mg}(50 \mathrm{mg} / \mathrm{k} / \mathrm{d})\end{array}$ & VPA $675 \mathrm{mg}(15 \mathrm{mg} / \mathrm{k} / \mathrm{d} \rightarrow 90 \mu \mathrm{g} / \mathrm{mL})$ CLB $10 \mathrm{mg}$ \\
\hline First symptoms & $\begin{array}{l}\text { Throat ache, mild fever, paracetamol, } \\
\text { clonic seizure, IR DZ } 10 \mathrm{mg}(0.3 \mathrm{mg} / \mathrm{k}) \\
\text { at home, then vomiting, respiratory } \\
\text { distress } \rightarrow \text { hospital }\end{array}$ & $\begin{array}{l}1 \text { seizure during sleep (unknown duration); no fever; oral MDZ } 10 \mathrm{mg} \text {; } \\
\text { T } 39^{\circ} \mathrm{C} \text {; coma } \rightarrow \text { hospital }\end{array}$ \\
\hline $\begin{array}{l}\text { At hospital status } \\
\text { temperature }\end{array}$ & $\begin{array}{l}\text { Seizure duration } 2 \text { h } 30 \\
\qquad 38-40{ }^{\circ} \mathrm{C}\end{array}$ & repeated seizures during 3 days, with coma and fever \\
\hline Treatment & $\begin{array}{l}\text { MDZ IV bolus }(0.1+0.2 \mathrm{mg} / \mathrm{k}) \\
\text { LEV IV bolus }(\mathrm{dose} ?) \\
\text { PHT IV }(15 \mathrm{mg} / \mathrm{k}) \\
\text { PB IV bolus }(10 \mathrm{mg} / \mathrm{k}) \rightarrow \text { stop } \\
\text { seizures } \rightarrow \text { persistent coma }\end{array}$ & $\begin{array}{c}\text { MDZ IV bolus }(0.1 \mathrm{mg} / \mathrm{k} \times 3) \text { followed by continuous IV MDZ } \\
\text { antibiotics + antipyretics }\end{array}$ \\
\hline MRI & $\begin{array}{l}\text { Day 5: diffuse cortical swelling }+ \\
\text { hypersignal subcortical white matter } \\
\text { Day 20: diffuse cortical atrophy }+ \\
\text { central nuclei and subcortical } \\
\text { white matter atrophy }\end{array}$ & $\begin{array}{l}\text { Day } 16 \text { (after the end of the episode): enlarged ventricular cavities and } \\
\text { subarachnoid spaces at the supra- and under-tentorial level, atrophy of } \\
\text { the cerebellar hemispheres. Previously existing abnormalities. }\end{array}$ \\
\hline Outcome & $\begin{array}{c}\text { Persistence of coma } \\
\text { Probably not epileptic tonic seizures } \\
\text { Treatment: oral VPA, LEV, } \\
\text { CLB + IV MDZ } \\
2 \text { months later: severe } \\
\text { sepsis and death. }\end{array}$ & $\begin{array}{c}\text { Coma duration: } 3 \text { days } \\
\text { General regression with motor, cognitive, speech deficit, improved by } \\
\text { intensive rehabilitation. } 18 \text { years: } 75 \% \text { recovery. No seizures. } \\
\text { Treatment: VPA + CLB id }\end{array}$ \\
\hline
\end{tabular}

Legend. ES: epileptic status; VPA: valproic acid; CLB: clobazam; LEV: levetiracetam; IR DZ: intrarectal diazepam; IV: intravenous; MDZ: midazolam; PHT: phenytoin; PB: phenobarbital; AEDs: antiepileptic drugs; MRI: magnetic resonance imaging.

Funding: This research received no external funding.

Informed Consent Statement: Informed consent was obtained from the parents of the patients presented here.

Acknowledgments: I acknowledge the family of the two patients who gave me the permission for this publication, and Evangelos Paraskevoulakos who helped me to complete the clinical information of Patient 2.

Conflicts of Interest: The author declares no conflict of interest. 


\section{References}

1. De Liso, P.; Pironi, V.; Mastrangelo, M.; Battaglia, D.; Craiu, D.; Trivisano, M.; Specchio, N.; Nabbout, R.; Vigevano, F. Fatal Status Epilepticus in Dravet Syndrome. Brain Sci. 2020, 10, 889. [CrossRef] [PubMed]

2. Oguni, H.; Hayashi, K.; Awaya, Y.; Fukuyama, Y.; Osawa, M. Severe myoclonic epilepsy in infants-A review based on the Tokyo Women's Medical University series of 84 cases. Brain Dev. 2001, 23, 736-748. [CrossRef]

3. Dravet, C.; Oguni, H.; Çokar, O.; Guerrini, R. Dravet Syndrome (Previously Severe Myoclonic Epilepsy in Infancy). In Epileptic Syndromes in Infancy, Childhood and Adolescence, 6th ed.; Bureau, M., Genton, P., Dravet, C., Delgado-Escueta, A.V., Guerrini, R., Tassinari, C.A., Thomas, P., Wolf, P., Eds.; John Libbey: London, UK, 2019; pp. 139-172.

4. Tian, X.; Ye, J.; Zeng, Q.; Zhang, J.; Yang, X.; Liu, A.; Yang, Z.; Liu, X.; Wu, X.; Zhang, Y. The clinical outcome and neuroimaging of acute encephalopathy after status epilepticus in Dravet syndrome. Dev. Med. Child Neurol. 2018, 60, 566-573. [CrossRef] [PubMed]

5. Okumura, A.; Uematsu, M.; Imataka, G.; Tanaka, M.; Okanishi, T.; Kubota, T.; Sudo, A.; Tohyama, J.; Tsuji, M.; Ohmori, I.; et al. Acute encephalopathy in children with Dravet syndrome. Epilepsia 2011, 53, 79-86. [CrossRef]

6. Myers, K.A.; McMahon, J.M.; Mandelstam, S.A.; Mackay, M.T.; Kalnins, R.M.; Leventer, R.J.; Scheffer, I.E. Fatal Cerebral Edema With Status Epilepticus in Children With Dravet Syndrome: Report of 5 Cases. Pediatrics 2017, 139, e20161933. [CrossRef] [PubMed]

7. Dravet, C. Acute encephalopathy after febrile status epilepticus: An underdiagnosed, misunderstood complication of Dravet syndrome. Dev. Med. Child Neurol. 2018, 60, 534. [CrossRef] [PubMed] 